\title{
New and Developing Therapies in Spinal Muscular Atrophy: From Genotype to Phenotype to Treatment and Where Do We Stand?
}

\author{
Tai-Heng Chen $1,2,3$ (D) \\ 1 Section of Neurobiology, Department of Biological Sciences, University of Southern California, \\ Los Angeles, CA 90089, USA; taihen@kmu.edu.tw \\ 2 Division of Pediatric Emergency, Department of Pediatrics, Kaohsiung Medical University Hospital, \\ Kaohsiung Medical University, Kaohsiung 80708, Taiwan \\ 3 Ph.D. Program in Translational Medicine, Graduate Institute of Clinical Medicine, Kaohsiung Medical \\ University and Academia Sinica, Taipei 11529, Taiwan
}

Received: 12 April 2020; Accepted: 4 May 2020; Published: 7 May 2020

\begin{abstract}
Spinal muscular atrophy (SMA) is a congenital neuromuscular disorder characterized by motor neuron loss, resulting in progressive weakness. SMA is notable in the health care community because it accounts for the most common cause of infant death resulting from a genetic defect. SMA is caused by low levels of the survival motor neuron protein (SMN) resulting from SMN1 gene mutations or deletions. However, patients always harbor various copies of $S M N 2$, an almost identical but functionally deficient copy of the gene. A genotype-phenotype correlation suggests that SMN2 is a potent disease modifier for SMA, which also represents the primary target for potential therapies. Increasing comprehension of SMA pathophysiology, including the characterization of SMN1 and SMN2 genes and SMN protein functions, has led to the development of multiple therapeutic approaches. Until the end of 2016, no cure was available for SMA, and management consisted of supportive measures. Two breakthrough SMN-targeted treatments, either using antisense oligonucleotides (ASOs) or virus-mediated gene therapy, have recently been approved. These two novel therapeutics have a common objective: to increase the production of SMN protein in MNs and thereby improve motor function and survival. However, neither therapy currently provides a complete cure. Treating patients with SMA brings new responsibilities and unique dilemmas. As SMA is such a devastating disease, it is reasonable to assume that a unique therapeutic solution may not be sufficient. Current approaches under clinical investigation differ in administration routes, frequency of dosing, intrathecal versus systemic delivery, and mechanisms of action. Besides, emerging clinical trials evaluating the efficacy of either SMN-dependent or SMN-independent approaches are ongoing. This review aims to address the different knowledge gaps between genotype, phenotypes, and potential therapeutics.
\end{abstract}

Keywords: spinal muscular atrophy; survival motor neuron protein; novel therapy; clinical care

\section{Introduction}

Spinal muscular atrophy (SMA) is an autosomal recessive neurodegenerative disease characterized by devastating muscular wasting caused by the progressive degeneration of spinal motor neurons (MNs). Although recognized as a rare disease with an estimated global incidence of $\sim 1 / 10,000$ live births, SMA has been regarded as a noteworthy health issue because it is not only the second most common autosomal recessive inherited disorder, but is also the most common monogenic disease leading to infant mortality [1,2]. The carrier frequency of SMA varies from 1 in 38 to 1 in 72 , depending on the racial group, with the pan-ethnic average being 1 in 54 [3]. 
Figure 1 illustrates the genetic pathomechanism of SMA. All patients with SMA have an insufficient amount of a survival motor neuron (SMN) protein, which is encoded by two highly homogenous genes, survival of motor neuron 1 (SMN1) and its copy gene, SMN2. SMN2 is differentiated from SMN1 by one single nucleotide variant $(\mathrm{C} \rightarrow \mathrm{T})$ in exon 7 . This critical difference results in the preferential exclusion of exon 7 from most ( $90 \%)$ SMN2 transcripts, termed SMN $\triangle 7$, which translates into truncated and unstable SMN protein. As a consequence, SMN2 can only generate $\sim 10 \%$ of full-length (FL) SMN mRNAs and their product-functional SMN proteins (Figure 1A). While these FL-SMN2 transcripts can partially compensate for the loss of SMN1, it is reasoned that retained SMN2 copy numbers of patients determine the phenotypic severity (Figure 1B). However, such a phenotype-genotype correlation is not absolute, as recent studies have indicated that additional cellular mechanisms (e.g., positive or negative disease modifiers) might also involve the modulation of SMA clinical severity. For example, rare SMN2 variants (c.859G > C), as well as independent modifiers such as plastin 3 or neurocalcin delta, can further influence the disease severity [4-6]. In brief, the loss of the SMN1 gene leads to SMA, whose severity is partially modified by various copies of SMN2.
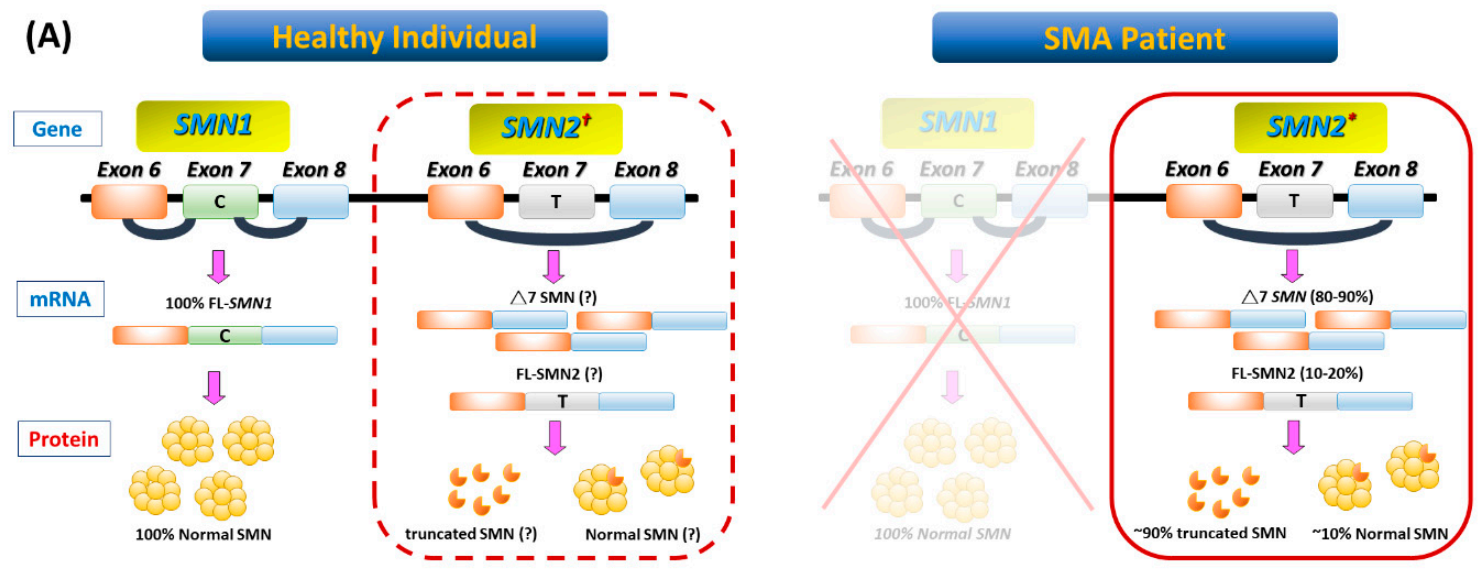

(B)

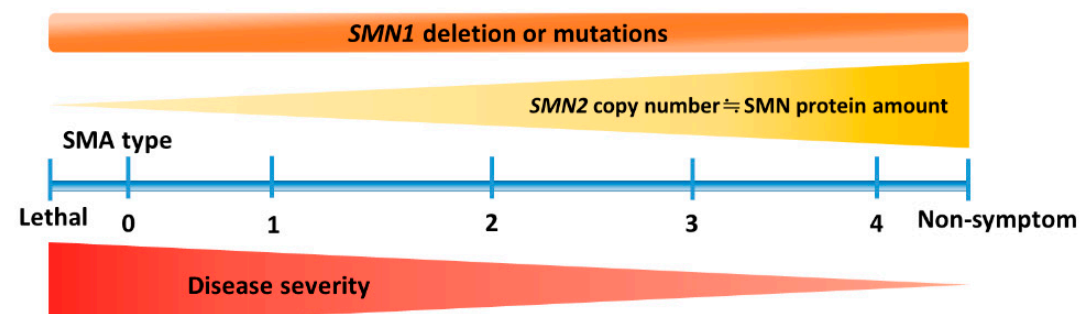

Figure 1. Genetic basis and phenotype-genotype correlation of spinal muscular atrophy (SMA). (A) In a healthy individual, full-length (FL) survival motor neuron (SMN) mRNA and protein arise from the SMN1 gene. Patients with SMA have homozygous deletion or mutation of SMN1 but retain at least one SMN2 (indicated with an asterisk in the solid-border box on the right). However, SMN2 can be dispensable in a healthy individual (indicated with an obelisk in the dotted-border box on the left). This single-nucleotide change in exon 7 (C-to-T) of SMN2 causes alternative splicing during transcription, resulting in most SMN2 mRNA lacking exon 7 ( $\triangle 7 \mathrm{SMN})$. About $90 \%$ of $\triangle 7 \mathrm{SMN}$ transcripts produce unstable truncated SMN protein, but a minority include exon 7 and code for FL, which maintains a degree of MN survival. (B) A continuous spectrum of phenotypes in SMA. Even with genetic confirmation of SMN1 absence or mutations in all patients, SMA presentation ranges from very compromised neonates (type 0 ) to adults with minimal manifestations (type 4) depending on the SMN2 numbers and FL SMN produced by each patient and modulated by potential disease modifiers that influence the final phenotype.

Understanding SMN protein functions and mechanisms of action in subcellular contexts may elucidate potential pathways for therapeutic intervention. SMN is a multifunctional protein that is 
ubiquitously expressed in most somatic cells [7]. The most appreciated canonical role of SMN is to serve as an essential component of small nuclear ribonucleoproteins (snRNPs) that form spliceosomes to process the pre-mRNA splicing [8,9]. Studies on SMA animal models have revealed a direct correlation between the ability to assemble snRNPs and SMA phenotypes [10]. SMN is also involved in DNA repair and mRNA transportation along MN axons [11]. However, the multifaceted roles of SMN protein are still under investigation, and it is unclear how a deficiency in ubiquitously expressed SMN can selectively cause the dramatic MN degeneration. The cell autonomous effects related to deficient SMN are responsible for the MNs' degeneration. However, this does not account for the full SMA phenotype, implicating not only the dysfunction of neural networks but other non-neuronal cell types involved in the disease process [12,13]. For example, recent studies indicate that the MN survival and functionality of SMA animal and cellular models is highly dependent on glial cells, which play an important role in neuronal communication and neuroinflammation $[14,15]$. These findings imply that SMA could also be a neuroinflammatory disease.

\section{Clinical Characteristics of SMA}

\subsection{SMA Phenotypes and Classifications}

SMA is classified into three main phenotypes based on age at the onset of symptoms/signs, and the highest motor function achieved $[3,6,16]$. However, some patients with SMA are outliers on either end of the phenotypic spectrum. Subclassification has also been proposed in SMA types 1 and 3, and sometimes in the type 2 phenotype (Table 1 and Figure 1B). It should be kept in mind that regardless of the type of SMA, severity may vary and change over time, because the disease is a continuum.

At one end of the spectrum, patients with type 0 SMA (categorized as type 1A by some authors) are usually associated with prenatal onset of signs such as a history of decreased fetal movements [17]. These rare cases usually present with arthrogryposis multiplex congenita and have profound hypotonia and respiratory distress soon after birth. Life expectancy is hugely reduced, and if untreated, most cases are unable to survive beyond one month of age [1,18].

Type 1 SMA patients account for more than $50 \%$ of the incidence of SMA. These patients are called non-sitters, who never achieve major motor developmental milestones such as sitting, standing, and walking in their lifetime. Notably, congenital heart defect is also a feature of severe SMA phenotype, especially in SMA types 0 and 1 [19]. If left untreated, most cases of mortality within the first two years of life are attributable to respiratory muscle dysfunction, with a median survival of 13.5 months [20].

Patients with type 2 SMA (Dubowitz's disease) are sitters who initially present with a delay in reaching developmental milestones for gross motor skills. Although these patients can maintain a sitting position unaided ("sitters") and a few can even stand with leg braces, none can walk independently. Kyphoscoliosis usually develops, complicated with restrictive lung disease if there are no orthopedic interventions. Cough and ability to clear airway secretions are usually progressively compromised. A majority of patients with type 2 SMA can survive into adulthood. However, after entering their adolescence, these patients usually require aggressive supportive management, especially regarding gastrointestinal and respiratory complications [21,22].

Patients with type 3 SMA (Kugelberg-Welander disease) are walkers who are able to stand unsupported and walk independently during their early life. These patients usually show profound symptom heterogeneity, so they are often misdiagnosed with myopathy or muscular dystrophy. The distribution of weakness is similar to that seen in patients with types 1 and 2 SMA, but the progression of weakness is much slower; some patients may eventually become wheelchair dependent at middle age [23]. At the other end of the spectrum is the mildest adult-onset form, known as type 4 SMA, where individuals present onset symptoms-usually a weakness of lower extremities-after the second decade. Type 4 patients have a good prognosis with ambulation into adulthood and a mostly average life span [24]. 
Table 1. Classification and subtypes of spinal muscular atrophy.

\begin{tabular}{|c|c|c|c|c|c|c|c|c|}
\hline $\begin{array}{c}\text { SMA Type } \\
\text { (Historical Name) }\end{array}$ & OMIM & Onset Age & $\begin{array}{c}\text { Motor } \\
\text { Milestones } \\
\text { Achieved }\end{array}$ & Subclassification & Natural History & Other Features & $\begin{array}{c}\text { Estimated } \\
\text { SMN2 Copies }\end{array}$ & $\begin{array}{l}\text { Estimated SMA } \\
\text { Proportion }\end{array}$ \\
\hline Type 0 & - & $\begin{array}{l}\text { Prenatal or at } \\
\text { birth }\end{array}$ & $\begin{array}{l}\text { Never sits, } \\
\text { never head } \\
\text { control }\end{array}$ & - & $\begin{array}{c}\text { Death }<1 \text { mo if } \\
\text { untreated }\end{array}$ & $\begin{array}{l}\text { Joint contractures, } \\
\text { cardiac defect, facial } \\
\text { diplegia, immediate } \\
\text { respiratory failure } \\
\text { after birth }\end{array}$ & $\begin{array}{c}1 \text { SMN2 copy in } \\
\sim 100 \% \text { of } \\
\text { patients }\end{array}$ & Unclear, Maybe $<1 \%$ \\
\hline $\begin{array}{c}\text { Type } 1 \\
\text { (Werdnig-Hoffmann } \\
\text { disease) }\end{array}$ & 253300 & $0-6 \mathrm{mo}$ & $\begin{array}{c}\text { Never sits, some } \\
\text { achieve } \\
\text { head control }\end{array}$ & $\begin{array}{c}\text { 1A: Onset }<1 \text { mo, usually } \\
\text { by } 2 \text { wk; head control } \\
\text { absent } \\
\text { 1B: Onset } 1-3 \text { mo; poor or } \\
\text { absent head control } \\
\text { 1C: Onset } 3-6 \text { mo; head } \\
\text { control achieved }\end{array}$ & $\begin{array}{c}\text { 1A: Death }<6 \\
\text { mo if untreated } \\
1 \mathrm{~B} \text { and } 1 \mathrm{C}: \\
\text { death }<2 \mathrm{yr} \text { if } \\
\text { untreated }\end{array}$ & $\begin{array}{l}\text { 1A: Very similar to } \\
\text { type 0 SMA } \\
\text { 1B and 1C: Tongue } \\
\text { fasciculation, } \\
\text { swallowing } \\
\text { difficulties, } \\
\text { early respiratory } \\
\text { failure }\end{array}$ & $\begin{array}{c}1 \text { or } 2 \text { SMN2 } \\
\text { Copies in } \sim 80 \% \\
\text { of patients }\end{array}$ & $\sim 60 \%$ \\
\hline $\begin{array}{c}\text { Type } 2 \\
\text { (Dubowitz disease) }\end{array}$ & 253550 & 7-18 mo & $\begin{array}{l}\text { Sits but never } \\
\text { stands }\end{array}$ & $\begin{array}{l}\text { 2A: Sits independently, } \\
\text { may lose the ability to sit } \\
\text { in later life } \\
\text { 2B: Sits independently, } \\
\text { maintains the ability to sit } \\
\text { According to functional } \\
\text { level, decimal } \\
\text { classification ranging } \\
\text { from } 2.1 \text { to } 2.9\end{array}$ & $\begin{array}{c}\text { Usually survive } \\
>2 \mathrm{yr} ; \\
\sim 70 \% \text { alive at } \\
25 \mathrm{yr}\end{array}$ & $\begin{array}{l}\text { Proximal weakness, } \\
\text { postural hand tremor, } \\
\text { normal intellectual } \\
\text { ability, kyphoscoliosis }\end{array}$ & $\begin{array}{c}3 \text { SMN2 copies } \\
\text { in } \\
>70 \% \text { patients }\end{array}$ & $\sim 27 \%$ \\
\hline $\begin{array}{c}\text { Type } 3 \\
\text { (Kugelberg-Welander } \\
\text { disease) }\end{array}$ & 253400 & $>18 \mathrm{mo}$ & $\begin{array}{l}\text { Stands and } \\
\text { walks }\end{array}$ & $\begin{array}{c}\text { 3A: Onset between } 18 \\
\text { and } 36 \text { mo } \\
\text { 3B: Onset }>3 \text { yr }\end{array}$ & $\begin{array}{l}\text { Survival into } \\
\text { adulthood }\end{array}$ & $\begin{array}{l}\text { May have hand } \\
\text { tremor, resembles } \\
\text { muscular dystrophy } \\
\text { 3A: Scoliosis, usually } \\
\text { early loss of } \\
\text { ambulation }\end{array}$ & $\begin{array}{l}3 \text { or } 4 \text { SMN2 } \\
\text { copies in } \sim 95 \% \\
\text { of patients }\end{array}$ & $\sim 12 \%$ \\
\hline Type 4 & 271150 & $\begin{array}{c}10-30 \mathrm{yr} \text {, usually } \\
>21 \mathrm{yr}\end{array}$ & $\begin{array}{l}\text { Stands and } \\
\text { walks }\end{array}$ & - & $\begin{array}{l}\text { Survival into } \\
\text { adulthood }\end{array}$ & $\begin{array}{l}\text { Usually preserved } \\
\text { walking ability }\end{array}$ & $\begin{array}{c}4 \text { or more } S M N 2 \\
\text { copies } \\
\text { in }>90 \%\end{array}$ & $\sim 1 \%$ \\
\hline
\end{tabular}

SMA: spinal muscular atrophy; mo: months; yr: years. 


\subsection{The Implication of Phenotypic Classification in SMA Clinical Trials}

Efforts to better understand the natural history and define outcome measures pave the way for the readiness of SMA trials $[25,26]$. Initially, the phenotype-genotype correlation encouraged the application of SMN2 copies as a criterion for patient enrollment in clinical trials [27]. However, discordant cases certainly exist, and the prediction of phenotype solely through SMN2 copies is not always accurate in individual cases [6]. Except for some disease modifiers, several prognostic factors have been identified [18]. Although the severity-based classification has clinical advantages, it is not always adequate to provide prognostic information or to facilitate the stratification of SMA patients. Rather than the SMA phenotype, the ambulant status may be more relevant to the trajectory of disease progression [28]. This approach acknowledges the SMA phenotypes as a continuum and focuses on the current functional status and the response to therapy. Furthermore, pulmonary function assessment may better reflect disease state than muscle strength [29]. Nevertheless, repeat evaluations are imperative before assigning a patient to a specific SMA type. Particularly in patients with SMA types 2 and 3, the onset, time course, and extent of MN loss has not been well established, yet are vital in determining whether there is a specific therapeutic window for these patients with milder phenotypes.

\section{Impacts of Evolving Supportive Care in SMA Therapeutic Era}

Advances in drug development are likely to impact the natural history of and care methods for patients with SMA $[28,30]$. An immediate benefit of multidisciplinary care and care coordination for SMA patients has been the development and distribution of standard-of-care (SOC) recommendations. In 2007, a consensus statement for the standard of care in SMA was released by a multidisciplinary team regarding the current best advice for the management of patients with SMA [31]. With the advent of disease-modifying treatment that became available in early 2017, a new two-part SOC consensus paper was published in 2018 [21,22]. The multidisciplinary team should and may include a variety of medical specialties that ideally follow up both the as-yet untreated patients as part of providing a SOC and patients that undergo specific therapies (Figure 2). As patients following SOC guidelines can receive same-level care to reduce the variability of disease progression, it is particularly crucial for those currently participating in clinical trials. Experts recommend that SMA patients on trial should be paired with adherence to SOC provided a core facility of a multidisciplinary care team $[16,28]$. As such, revolving SOC guidelines for SMA have assumed a more substantial role of defining what is meant by optimal or even required care.

In the therapeutic era, we reasonably expect that type 1 SMA patients will likely transition into less severe types 3 and 4 once treated, giving them a more extended or average lifespan. It remains unclear whether persistent interventions will be required, and a complete long-term reversal of symptoms will be attained. Unfortunately, because there is a paucity of studies investigating the support and medical needs of type 4 SMA patients (and soon the treated patients), it is unknown whether such lifespan extension will reveal new, previously unknown, comorbidities that could arise with age in this new, modified SMA affected population. In parallel with pre-clinical advances, continued evolution in multidisciplinary care with technological advances should be pursued, particularly for those with milder phenotypes after disease-modifying therapy. 


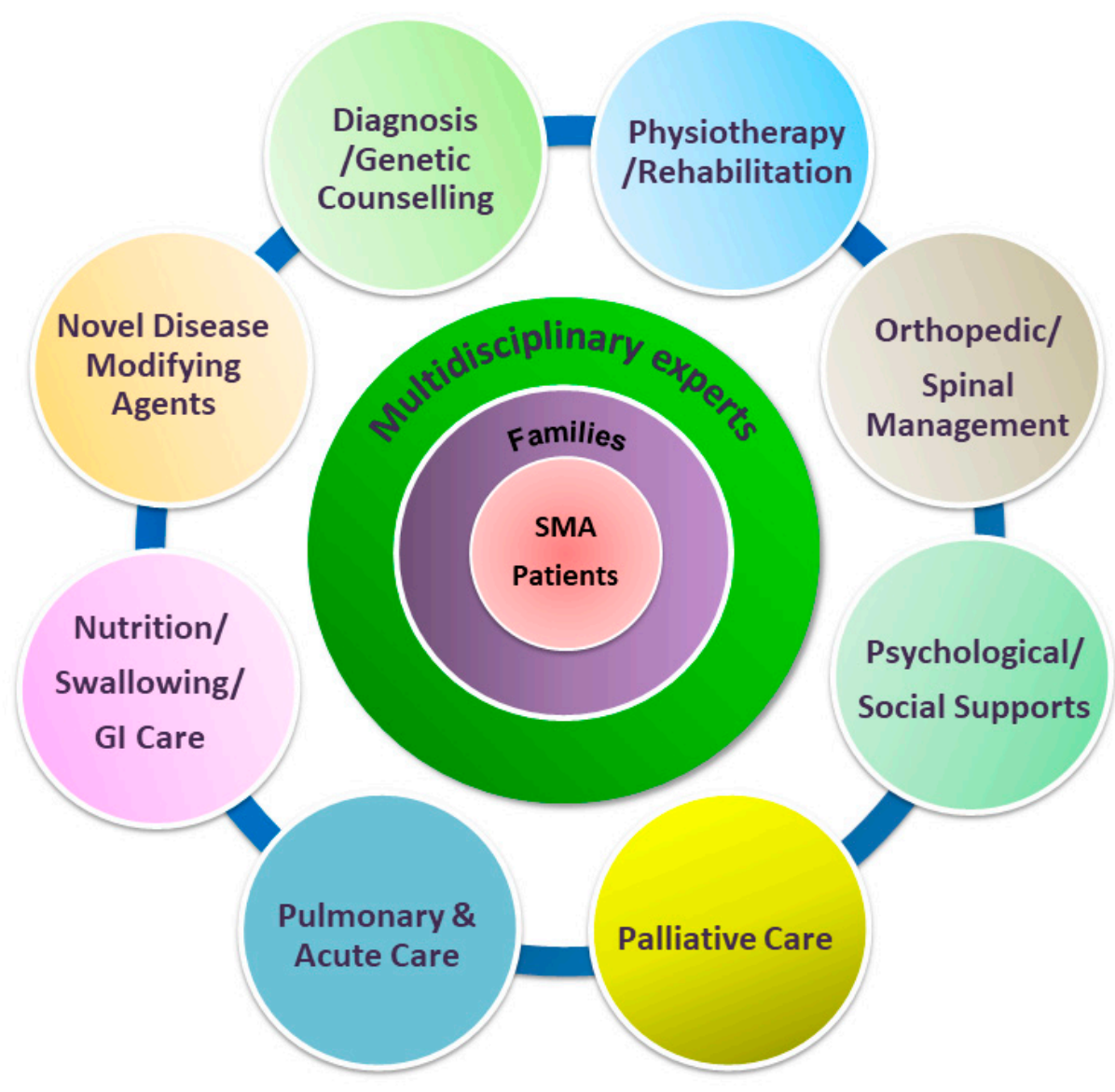

Figure 2. Paradigm of multidisciplinary care of SMA, incorporating disease-modifying therapies with supportive care. Novel disease-modifying medications and evolving multidisciplinary supportive management need to occur concomitantly to achieve the best possible outcome for SMA patients.

\section{Recent Advances in Innovative Therapeutic Approaches for SMA: Focusing SMN and Beyond}

In general, the therapeutic strategies in SMA can be categorized either as SMN-dependent therapies or as $\mathrm{SMN}$-independent therapies, which can be subsequently divided into eight different therapeutic approaches (Figure 3). Deletion or mutation of SMN1 is partially compensated by limited expression of SMN protein produced by variable SMN2 copies, which provide a therapeutic target [32]. With the proof-of-concept, the initial approaches mostly aim to target SMN2 in the treatment of SMA [33,34]. However, increasing evidence extend the pathogenic effect of SMN deficiency beyond MNs to include additional cells both within and outside the CNS, whereby numerous peripheral organs and non-neuronal tissues (e.g., cardiovascular system, immune system, gastrointestinal tract, and kidneys) have demonstrated pathological changes in pre-clinical models and patients [12,30,35-38].

We summarize the updated information of pre-clinical and clinical trials for potential therapeutic agents in Table 2. The precise characterization of SMN-dependent and SMN-independent pathways that are both affected and underlying the disease remains a critical aspect of developing therapeutic approaches for SMA. Among different approaches, strategies with the most promising clinical data for SMA have been achieved through upregulating FL SMN2 production by modulating splicing or replacing functional exogenous SMN1 gene via a viral vector $[39,40]$. These two therapies have been officially approved within the past two years. In parallel with the treatment pipeline of SMN-dependent approaches, neuroprotective agents, myostatin inhibitors, skeletal muscle troponin activators, and stem cell therapy are examples of adjunctive SMN-independent therapies [41]. Importantly, recent breakthroughs in novel therapies for SMA may also inspire similar approaches for other genetic motor neuron diseases. For example, similar therapeutic strategies are proposed to applied to spinal muscular 
atrophy with respiratory distress type 1 (SMARD1) caused by IGHMBP2 gene mutation is a non-5q SMA, which is the second most common motor neuron disease of infancy following SMA [42].

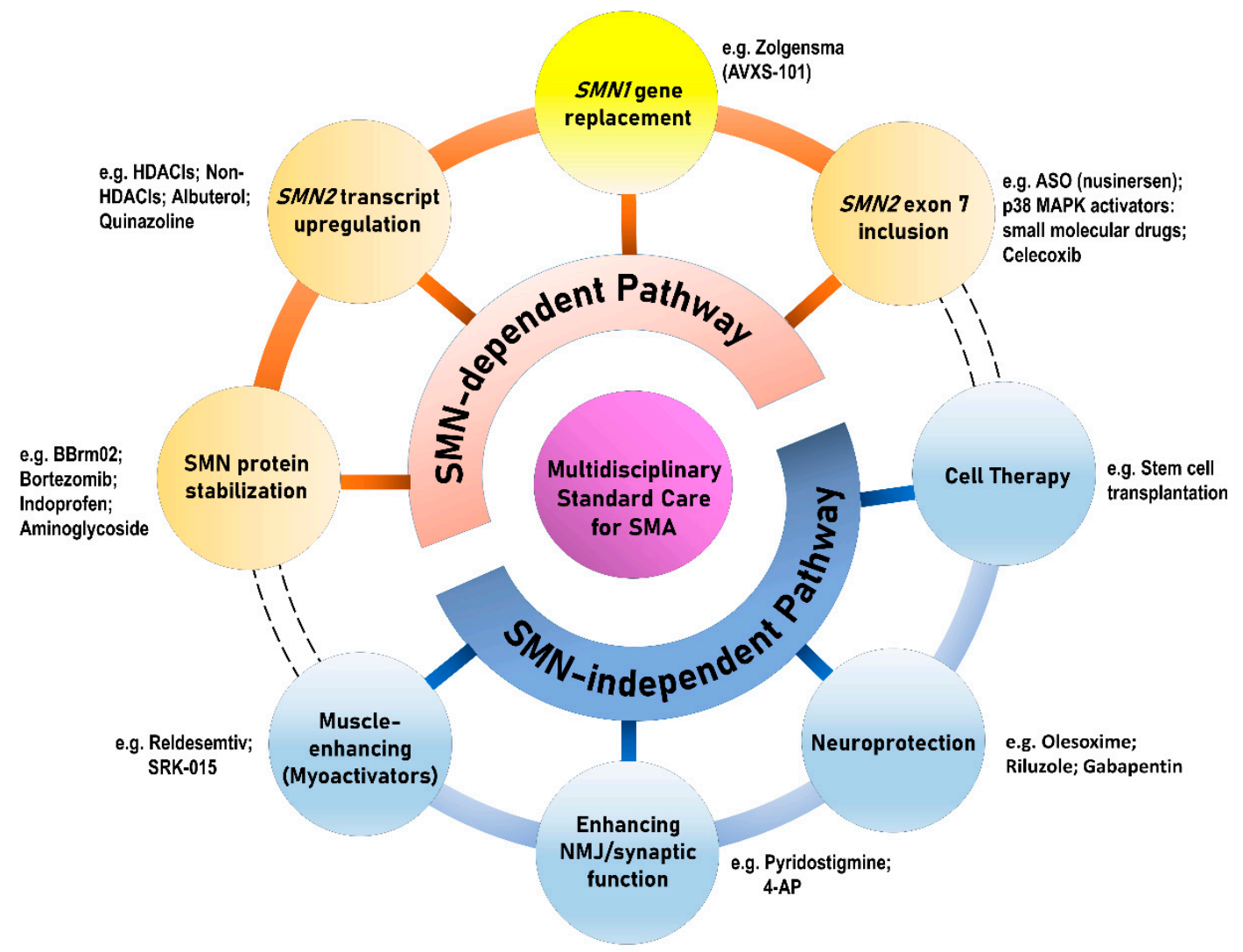

Figure 3. Therapeutic approaches for SMA. ASO: antisense oligonucleotide; HDACI: histone deacetylase inhibitor; NMJ: neuromuscular junction.

In the following, we discuss how the current SMN-targeting compounds that are presently in clinical trials inform the potential development of treatments aimed at non-SMN targets in non-CNS tissues. We also discuss the critical role of supportive care methods in the era of SMA therapeutics.

The therapeutic approaches for SMA are generally categorized into SMN-dependent and SMN-independent therapies, which can be further divided into four branches of development, respectively. The yellow circle in Figure 3 indicating SMN1 gene replacement therapy of the SMN-dependent pathway highlights its difference from the other three therapies in the SMN-dependent category, which mainly target SMN2. The dashed lines of the outer rims connecting the SMN-dependent and SMN-independent approaches imply the potential for combinatory effect as a "cocktail therapy" for SMA. 
Table 2. Novel therapeutic approaches in spinal muscular atrophy: current clinical and preclinical trials.

\begin{tabular}{|c|c|c|c|c|}
\hline Therapeutic Pathways & Pathologic Points & Therapeutic Targets & Therapeutic Agents & Trial Status (Completed or Ongoing)/Results \\
\hline \multirow{4}{*}{ SMN-dependent } & SMN1 mutation & SMN1 replacement & Zolgensma (AVXS-101) & FDA-Approved \\
\hline & $\begin{array}{l}\text { Alternative splicing of } S M N 2 \\
\text { mRNA }\end{array}$ & Promote exon 7 inclusion & $\begin{array}{ll}\text { - } & \text { Nusinersen (Spinraza) } \\
\text { - } & \text { Risdiplam (RG7916) } \\
\text { - } & \text { Branaplam (LMI070) }\end{array}$ & $\begin{array}{l}\text { - } \quad \text { Nusinersen: FDA-approved } \\
\text { - Risdiplam: ongoing phase 2/3 placebo-controlled; } \\
\text { approaching FDA-approved } \\
\text { - } \quad \text { Branaplam: ongoing phase } 1 / 2 \text { open-label }\end{array}$ \\
\hline & $\begin{array}{l}\text { Decreased full length SMN } \\
\text { mRNA }\end{array}$ & $\begin{array}{l}\text { Upregulation of SMN2 } \\
\text { transcript }\end{array}$ & $\begin{array}{ll}\text { - } & \text { HDACIs, e.g., PBA, VPA, } \\
\text { - } & \text { Non-HDACIs: Hydroxyurea } \\
\text { - } & \text { Quinazoline (RG3039) } \\
\text { - } & \text { Albuterol } \\
\text { Prolactin }\end{array}$ & $\begin{array}{ll}\text { - } & \text { PBA: completed placebo-controlled; negative } \\
\text { - } & \text { VPA: completed placebo-controlled; negative } \\
\text { - } & \text { Hydroxyurea: completed } \\
\text { - } & \text { Clacebo-controlled; negative } \\
\text { - } & \text { Quinazoline: suspended } \\
\text { - } & \text { Albuterol: completed open-label; positive but } \\
\text { - } & \text { lacking large controlled trials data } \\
\text { Prolactin: preclinical }\end{array}$ \\
\hline & SMN protein degradation & Stabilizing SMN protein & $\begin{array}{ll}\text { - } & \text { Aminoglycoside } \\
\text { - } & \text { Bortezomib } \\
\text { - } & \text { BBrm02 } \\
\text { - } & \text { Indoprofen } \\
\text { - } & \text { polyphenols }\end{array}$ & All are preclinical \\
\hline \multirow{4}{*}{ SMN-independent } & Anabolic abnormalities & $\begin{array}{l}\text { Muscle-enhancing agent } \\
\text { (Myoactivators) }\end{array}$ & $\begin{array}{ll}- & \text { SRK-015 } \\
- & \text { Reldesemtiv (CK-2127107) } \\
- & \text { BIIB110 (ALG 801) } \\
- & \text { Follistatin }\end{array}$ & $\begin{array}{ll}\text { - } & \text { SRK-015: ongoing phase } 2 \text { open-label } \\
\text { - } & \text { Reldesemtiv: completed phase } 2 \\
& \text { placebo-controlled; pending } \\
\text { - } & \text { BIIB110: ongoing phase 1a } \\
\text { - } & \text { Follistatin: preclinical }\end{array}$ \\
\hline & Neuromuscular junction defect & $\begin{array}{l}\text { Enhancing } \\
\text { neurotransmitters }\end{array}$ & $\begin{array}{ll}- & \text { Pyridostigmine (Mestinon) } \\
\text { - } & \text { 4-aminopyridine (4-AP) }\end{array}$ & $\begin{array}{l}\text { - Pyridostigmine: completed placebo-controlled } \\
\text { trial; pending } \\
\text { - } 4 \text {-aminopyridine: completed placebo-controlled } \\
\text { trial; pending }\end{array}$ \\
\hline & Motor neuron loss & Neuroprotection & $\begin{array}{ll}\text { - } & \text { Riluzole } \\
\text { - } & \text { Gabapentin } \\
\text { - } & \text { Olesoxime (TRO19622) }\end{array}$ & $\begin{array}{l}\text { - } \quad \text { Riluzole: completed open-label; negative } \\
\text { - } \quad \text { Gabapentin: placebo-controlled trial; negative } \\
\text { - } \quad \text { Olesoxime: suspended }\end{array}$ \\
\hline & & $\begin{array}{l}\text { Cell therapy for } \\
\text { neurotrophic support }\end{array}$ & Stem cells & Preclinical \\
\hline
\end{tabular}




\section{SMN-Dependent Therapies for SMA}

Because of the presence of $S M N 2$, a well-validated target for therapeutic interventions, researchers have regarded SMA as a paradigm of "translational" disease. As a proof-of-concept, the most tempting approach in treating SMA is to upregulate $S M N 2$, retaining in all patients, to function as the missing SMN1, either by activating the SMN2 gene or by modulation of $S M N 2$ splicing [1,3,6,30]. As shown in Table 2, this idea prompted investigations into the upregulation of $S M N 2$ transcription by activating promoter, enhancing exon 7 inclusion, introducing SMN1 gene via a viral vector, modulating SMN protein translation, and preventing SMN protein degradation.

\subsection{Previous SMN-Dependent Trials with Indefinable Outcomes}

Histones are core proteins of chromatin that play a role in the epigenetic regulation of gene expression via their acetylation status. Early studies investigated the therapeutic potential of histone deacetylase inhibitors (HDACIs) and demonstrated their ability to increase SMN2 transcription through the modification of chromatin structure in vitro and in vivo SMA models [34,43]. Several potential HDACIs have been proposed to benefit SMA, including valproic acid, phenylbutyrate, and trichostatin A, which have been demonstrated to activate the SMN2 promotor, driving increased FL SMN [41,44]. However, regardless of any putative effect observed in vitro, no beneficial effect of HDACIs has carried over to clinical trials [45]. Otherwise, it seems that HDACIs are not exclusively specific to SMN, thus leading to a potential for side effects and potential dose limitations $[43,46]$.

Besides histone acetylation, several molecular mechanisms (e.g., histone phosphorylation, ubiquitination, and DNA methylation) are known to affect SMN2 expression [47]. Hydroxyurea, an FDA-approved non-HDACI agent, was found to increase the amount of FL SMN transcript and protein in vitro [48]. However, a small pilot trial on types 2 and 3 SMA showed no statistically significant benefit [49], followed by negative results of a further placebo-controlled trial [50].

Albuterol is a $\beta$-adrenergic agonist which has been shown to increase FL SMN transcript levels in vivo [51]. Two open-label trials of albuterol showed increased FL-SMN transcripts and improvements of motor function in types 2 and 3 SMA patients [52,53]. However, no data of further placebo-controlled trials are available in order to validate the benefit of albuterol in clinical practice for SMA [41].

Despite promising pre-clinical data, there are negative results following clinical trials of valproic acid combined with acetyl-L-carnitine, phenylbutyrate, hydroxyurea, and somatotropin. Their further development was discontinued, yet albuterol is still broadly prescribed off-label. However, these negative studies have informed clinical trial design, validated the reliability and feasibility of specific outcome measures, and highlighted the importance of patient stratification [30,54].

\subsection{Nusinersen: The First Approved Splicing-Modify Therapy for SMA}

Researchers first discovered an intronic splicing silencer N1 (ISS-N1) sequence in intron 7 of SMN2 involved in mRNA exon 7 skipping [55]. Inhibiting ISS-N1 motifs by antisense oligonucleotides (ASOs) was shown to enhance SMN2-mRNA exon 7 inclusion, and improved SMA phenotypes [56,57]. In 2011, a phase 1 trial of nusinersen, one of the ASOs with the greatest potential, demonstrated safety and effectiveness in SMA patients through delivery into the cerebrospinal fluid (CSF) space [58]. The subsequent phase 3 placebo-controlled trial (ENDEAR) showed a significant improvement in motor function and survival in treated infants with type 1 SMA [40]. Nusinersen was approved by the Food and Drug Administration (FDA) in late December 2016, and by the European Medicines Agency in June 2017.

To date, more than 8000 SMA patients have undergone nusinersen therapy worldwide [6]. However, besides a high price tag of $\$ 750,000$ for the first year of treatment, questions about its long-term efficacy abound, and there are some restrictions to the use of nusinersen. First, preclinical studies suggest a discrete time-window in neuromuscular development when increasing SMN levels are most effective [59]. The data from human trials also support the importance of a therapeutic 
window for a SMN-augmented treatment [60]. Unfortunately, SMA newborn screening programs have not yet been extensively performed worldwide or even nationwide [61,62]. On the other hand, patients with later-onset type 2 SMA showed significant motor improvement after treatment [63]; however, whether the long-term effect will be seen when treatment is initiated in the later SMA phase with slow decline is still unclear [64].

Second, because nusinersen cannot penetrate the blood-brain barrier (BBB), beyond which the targeted rescuing MNs lie, there is unfortunately no practical alternative to periodic intrathecal administration. The risks of performing lumbar puncture in SMA patients include exacerbating respiratory compromise related to knee-to-chest flexion posture during the procedure, headache, and CSF leakage. Without modern imaging assistance, repeated intrathecal injections can present challenges in some chronic SMA patients with significant scoliosis [65].

Third, the direct delivery of nusinersen into the spine restricts SMN upregulation only at the CNS; however, there is emerging evidence that SMN also plays a vital role in peripheral tissues $[66,67]$. Previous studies also demonstrated that peripheral SMN restoration compensates for its deficiency in the CNS and preserves MNs $[68,69]$. However, because there is still no patient natural history available to validate the correlation between low SMN and the vulnerability of other organs beyond MNs, the systemic ASO delivery in a human trial is still under evaluation [65].

\subsection{Gene Therapy for SMA: SMN1 Gene Replacement}

Contrary to augmenting SMN production via targeting SMN2, another therapeutic approach aims to transfer the SMN1 gene into the neural cells. Among various gene-delivery vectors, the self-complementary adeno-associated virus 9 (AAV9) was found to be the most promising because it is able to cross the BBB, and infected approximately $60 \%$ of MNs [70]. Besides, sustained human $S M N 1$ expression enhances rapid and efficient SMN production, which has been approved for in vivo study [71,72].

The first AAV9-SMN1 gene therapy, Zolgensma (AVXS-101 or onasemnogene abeparvovec), was administered in 15 type 1 SMA patients, and showed a significant improvement in motor and survival in a phase 1/2a trial [39]. The follow-up study further verified a significant efficacy of early therapy [73]. The preliminary data from an ongoing open-label phase 3 trial of type 1 SMA infants continue to demonstrate promising results [74]. However, the FDA has recently placed a partial hold on intrathecal Zolgensma administration in older SMA patients ( $\geq 2$ years and $<5$ years) based on safety concerns [75].

Because of different study designs, it is difficult to compare the efficacies between currently approved ASO-based and gene-based SMA therapies. However, the mean age of the patients was slightly lower in the Zolgensma trial than in the nusinersen trial (3.4 months vs. 5.4 months). There are several advantages of scAAV9-based gene therapy that make it potentially superior to ASO SMN-augmentation therapy [76]. First, scAAV9 gene therapy may require only a single intravenous infusion with a sustainable effect, whereas nusinersen probably requires lifelong repetitive intrathecal treatment. Second, given that SMN protein is ubiquitously expressed, systemic intravenous delivery of the AAV-vector gene has the advantage of increasing SMN expression in other organs in the body [6].

Nevertheless, there are still several concerns to be addressed, as independent studies with AAV9-SMN gene therapy administered through the intravenous route in large animals have shown suboptimal outcomes $[77,78]$. One of the notable concerns of AAV9-based gene therapy is the ubiquitous expression of SMN, leading to the nonspecific sequestration of essential RNAs and proteins through RNA-protein and protein-protein interactions, respectively. Furthermore, poor body-wide delivery of viral particles and likely immune response remains a concern for approaches based on gene replacement therapy [79].

\subsection{Risdiplam}

A small molecule agent, RG7800, was demonstrated to increase FL-SMN2 transcripts in laboratory studies and human safety in a phase 1 trial of SMA patients [80]. However, dosing was suspended due 
to off-target retinal effects in long-term, nonclinical safety studies in monkeys [81]. Another modified RG7800-like compound, Risdiplam (RG7916), showed a comparative efficacy in in vitro and in vivo studies, as well as in human pharmacokinetic data [82]. The potential of distribution in both central and peripheral tissues makes Risdiplam a potent therapeutic agent for addressing SMA as a whole-body disease [83]. Both trials in type 1 SMA patients (FIREFISH) and in types 2 and 3 patients (SUNFISH) demonstrated not only a significant increment of SMN protein in the blood but also an improvement of motor function with event-free survival $[84,85]$.

\subsection{Branaplam}

Branaplam (LMI070) can interact with U1 snRNP to facilitate exon 7 inclusion of SMN2 transcript, and thereby increases SMN protein levels and improves phenotypes [86]. An active phase $\frac{1}{2}$ clinical trial of Branaplam is an open-label, first-in-human study with oral administration to evaluate the safety and efficacy in patients with type 1 SMA. The preliminary results showed significant improvement in the motor functions after 86 days of treatment. Five patients continued to improve after 127 days of treatment [87].

\subsection{Celecoxib}

Treatment with celecoxib, a cyclooxygenase 2 inhibitor, was shown to increase SMN in SMA cell and animal models [88]. Celecoxib has several advantages in treating SMA, including the ability to cross the BBB and favorable safety profiles in humans. A phase 2 trial in patients with SMA types 2 and 3 is actively recruiting patients [41]. It may be with the hope that celecoxib may serve as adjunctive therapy for SMA, particularly given the low safe doses required for SMN induction.

\subsection{Quinazoline}

Blocking of decapping scavenger enzyme (DcpS) has been shown to increase FL-SMN2 transcript through upregulating SMN2 promoter activity [89]. Quinazoline (Repligen or RG3039), a DcpS inhibitor, was demonstrated to increase SMN protein and survival in SMA mice [90]. However, a phase $1 \mathrm{~b}$ trial showed that even though RG3039 successfully blocked DcpS in patients' blood, the SMN protein level did not change significantly [91]. Therefore, the pharmaceutic company concluded that RG3039 would be ineffective in SMA patients, and the further trial was halted [92].

\subsection{SMN Protein Stabilizers}

Aminoglycoside antibiotics (from a class of FDA-approved drugs including tobramycin, geneticin, and amikacin) can mask premature stop codon mutations and promote read-through of exon 8 , and thereby stabilize or increase the SMN level in patient fibroblasts [93,94]. However, they have only shown in vivo efficacy, and the toxicity has yet to be tested in animal models of SMA [46].

BBrm2 is a repurposed FDA-approved azithromycin acting on stop codon read-through, which was found to increase SMN in SMA patient cell lines and improve motor function and survival when intrathecally delivered in an SMA mouse model [46]. The pre-clinical trial was extended to another SMA mouse model, which also showed promising data [95].

Bortezomib is a ubiquitin proteasome inhibitor known to prevent SMN protein degradation. It has been shown to increase SMN protein in cultured cells and peripheral tissues of SMA model mice. Bortezomib-treated animals had improved motor function, which was associated with reduced spinal cord and muscle pathology and improved neuromuscular junction size, but no change in survival [96].

\section{SMN-Independent Therapies for SMA}

As the first SMN-dependent therapies are emerging into the clinical arena, other approaches beyond SMN augmentation are also under active investigation. However, $\mathrm{SMN}$-dependent approaches pose a particular challenge for patients with chronic forms (types 3 and 4) of SMA, who are often 
diagnosed beyond the critical therapeutic window [97]. For the patients with the chronic form of SMA with a substantial loss of MNs, it is more crucial to target the SMN-independent pathways disrupted downstream of SMN. Furthermore, emerging evidence has substantiated that SMA is a systemic disorder that goes beyond motor neurons. Identifying non-SMN targets to develop combinatorial therapeutic approaches is tempting because a comprehensive whole-lifespan approach to SMA therapy is required that includes both SMN-dependent and SMN-independent strategies that treat the CNS and periphery together $[6,98]$.

\subsection{Neuroprotective Agents}

Olesoxime (TRO19622) is a trophos cholesterol-oxime compound family of mitochondrial pore modulators with neuroprotective properties. Pre-clinical studies suggest that it improves the function and survival of neurons [99]. A phase 2 placebo-controlled trial in patients with types 2 and 3 SMA showed stabilized motor function at 24 months of treatment [100]. However, a subsequent follow-up study at 18 months did not demonstrate a significant clinical benefit (OLEOS, NCT02628743), and the pharmaceutical company announced that it was ending the development of olesoxime for SMA in June 2018 [6].

Other potentially neuroprotective agents, riluzole and gabapentin, have been investigated for their effects in treating SMA [101,102]. A phase 2/3 multicenter, randomized, double-blind study to assess the efficacy and safety of riluzole in young adults with types 2 and 3 SMA has been completed. Unfortunately, most of the results were not encouraging, or the studies were not adequate to show efficacy $[1,41]$.

\subsection{Myostatin Inhibitors}

Recently, most of the SMN-independent therapies have focused on muscle, since muscle weakness is always prominent in SMA. Myostatin is a growth factor produced primarily in skeletal muscle cells to inhibit muscle growth. Theoretically, blocking the myostatin signaling pathway can induce increased muscle mass and consequently improve muscle strength and motor function [103]. Follistatin is an endogenous antagonist of myostatin, and over-expression of recombinant follistatin in SMA mouse muscle leads to increased skeletal muscle mass as well as survival [104]. On the other hand, inhibition of activin receptor type IIB (ActRIIB) ligands can promote muscle growth, which suggests a potential therapy for neuromuscular disorders, including SMA. The systemic delivery of AAV-mediated soluble inhibitor of ActRIIB showed improvements in both muscle mass and muscle function in the SMA mouse model [105]. BIIB 110 (ALG 801) is a recombinant inhibitor of ActRIIB, which is undergoing a phase 1a trial [106].

Another myostatin inhibitor, SRK-015 (Scholar Rock), is a human monoclonal antibody found to increase muscle mass in SMA mice [107]. A phase 2 trial in type 2 and type 3 SMA patients through monthly intravenous administration is underway, and the preliminary data demonstrated a robust and dose-dependent target engagement on myostatin precursor [108].

\subsection{Skeletal Muscle Troponin Activator: Reldesemtiv}

Reldesemtiv (CK-2127107) is a fast skeletal muscle troponin activator which has been shown to improve muscle function and physical performance in SMA [46]. Reldesemtiv was demonstrated to increase skeletal muscle force in response to nerve stimulation, associated with a calcium-sensitizing effect [109]. With promising results demonstrating prolonged stamina and a modest improvement in pulmonary function [110], a double-blind phase 2 trial is ongoing to examine the efficacy of oral administration twice a day in non-type 1 SMA patients [111].

\subsection{Agents Targeting Neuromuscular Junction, Synapse, or Neurotransmitter}

Pyridostigmine (Mestinon) is an anti-acetylcholinesterase drug approved for treating myasthenia gravis. Researchers believe that the medicine's ability to activate and strengthen muscles might benefit 
SMA patients [112]. A placebo-controlled trial of pyridostigmine is ongoing to test the effects on muscle strength and fatigue in patients with types 2-4 SMA [113].

4-Aminopyridine (4-AP or Ampyra), a broad-spectrum inhibitor of potassium channels, is approved by the FDA for multiple sclerosis treatment. 4-AP was shown to improve the phenotypes of SMA in a Drosophila model, possibly through the pathway of motor circuits [114]. A phase 2/3 clinical trial assessing the efficacy in walking ability and endurance of type 3 adult SMA patients was completed in 2017, and the results are pending [115].

\subsection{Stem Cell Therapy}

The potential of cell therapy in SMA is related to the ability of stem cells to provide support to endogenous degenerating MNs [116]. Two currently available stem cell transplantation studies for SMA showed that primary neural stem cells injected into the spinal canal engrafted to the spinal cord, improved motor function, and extended survival $[117,118]$. However, these results have only reflected benefits likely with trophic support but without evidence of functional cell replacement. Accurate validation of therapeutic impact and a precise definition of the mechanism of action is still pending.

\section{Combination Therapy for SMA}

The concept that a combination of different therapeutic strategies could maximize the benefits for SMA treatment is intriguing. Although combined therapies with expensive drugs may at some point be prohibitive, limited data support the efficacy of such combinations on humans, and physicians and scientists are encouraged to explore all therapeutic possibilities [119]. Excitingly, a combined approach using SMN-dependent ASO-inducing SMN2 exon inclusion and SMN-independent myostatin inhibition have shown a favorable result in an SMA animal model [120]. Combined treatment with Zolgensma and nusinersen has recently been investigated in a small group of patients, although the long-term benefit is still unclear [121]. Zolgensma and nusinersen have different mechanisms of action, so the drug-to-drug interaction is less likely. Nusinersen works by targeting an intron sequence to enhance exon 7 inclusion. However, a transferred gene of Zolgensma does not contain any introns, so its translation should not interfere with nusinersen [98]. Because thrombocytopenia has been reported as an adverse event in association with nusinersen, caution is required when Zolgensma treatment is considered. Longer-term follow-up data, especially in the treatment of pre-symptomatic patients, should be accumulated to assess the efficacy and risks of combination therapy.

\section{Conclusions}

Although two SMN-dependent therapies have entered the market, neither of them has been proved to provide a cure. Ongoing research is continuing to pursue more potential agents through the development of novel compounds. Each of the treatments mentioned above could be promising in treating SMA. However, we are facing a rapidly changing landscape in SMA because of the perspectives of novel therapeutics relying on a greater understanding of SMA pathomechanisms, as well more abundant knowledge of the natural history and the impact of wide-spread multidisciplinary care. With the increasing number of therapies for SMA, ethical and thoughtful consideration of all players (industry, the health-care system, patients, and caregivers) will soon be necessary. Support groups such as the SMA Foundation, CureSMA, and Fight SMA have played a vital role in research efforts, in addition to providing a community for families affected by SMA.

Funding: This research was funded by the Ministry of Science and Technology (Taiwan), grant number MOST107-2314-B-037-066 and MOST108-2314-B-037-073; Kaohsiung Medical University Hospital in Kaohsiung, Taiwan, grant number KMUH-108-8R47.

Conflicts of Interest: The author declares no conflict of interest. 


\section{References}

1. Darras, B.T. Spinal muscular atrophies. Pediatr. Clin. N. Am. 2015, 62, 743-766. [CrossRef]

2. Kolb, S.J.; Kissel, J.T. Spinal muscular atrophy: A timely review. Arch. Neurol. 2011, 68, 979-984. [CrossRef] [PubMed]

3. Lunn, M.R.; Wang, C.H. Spinal muscular atrophy. Lancet 2008, 371, 2120-2133. [CrossRef]

4. Prior, T.W.; Krainer, A.R.; Hua, Y.; Swoboda, K.J.; Snyder, P.C.; Bridgeman, S.J.; Burghes, A.H.; Kissel, J.T. A positive modifier of spinal muscular atrophy in the smn2 gene. Am. J. Hum. Genet. 2009, 85, 408-413. [CrossRef]

5. Crawford, T.O.; Paushkin, S.V.; Kobayashi, D.T.; Forrest, S.J.; Joyce, C.L.; Finkel, R.S.; Kaufmann, P.; Swoboda, K.J.; Tiziano, D.; Lomastro, R.; et al. Evaluation of SMN protein, transcript, and copy number in the biomarkers for spinal muscular atrophy (BforSMA) clinical study. PLoS ONE 2012, 7, e33572. [CrossRef]

6. Wirth, B.; Karakaya, M.; Kye, M.J.; Mendoza-Ferreira, N. Twenty-Five Years of Spinal Muscular Atrophy Research: From Phenotype to Genotype to Therapy, and What Comes Next. Annu. Rev. Genom. Hum. Genet. 2020, 21, 4.1-4.31.

7. Singh, R.N.; Howell, M.D.; Ottesen, E.W.; Singh, N.N. Diverse role of survival motor neuron protein. Biochim. Biophys. Acta Gene Regul. Mech. 2017, 1860, 299-315. [CrossRef]

8. Dostie, J.; Mourelatos, Z.; Yang, M.; Sharma, A.; Dreyfuss, G. Numerous microRNPs in neuronal cells containing novel microRNAs. RNA 2003, 9, 180-186. [CrossRef]

9. Burghes, A.H.; Beattie, C.E. Spinal muscular atrophy: Why do low levels of survival motor neuron protein make motor neurons sick? Nat. Rev. Neurosci. 2009, 10, 597-609. [CrossRef] [PubMed]

10. Gabanella, F.; Butchbach, M.E.; Saieva, L.; Carissimi, C.; Burghes, A.H.; Pellizzoni, L. Ribonucleoprotein assembly defects correlate with spinal muscular atrophy severity and preferentially affect a subset of spliceosomal snRNPs. PLoS ONE 2007, 2, e921. [CrossRef]

11. Murray, L.M.; Beauvais, A.; Gibeault, S.; Courtney, N.L.; Kothary, R. Transcriptional profiling of differentially vulnerable motor neurons at pre-symptomatic stage in the Smn (2b/-) mouse model of spinal muscular atrophy. Acta Neuropathol. Commun. 2015, 3, 55. [CrossRef]

12. Hamilton, G.; Gillingwater, T.H. Spinal muscular atrophy: Going beyond the motor neuron. Trends Mol. Med. 2013, 19, 40-50. [CrossRef] [PubMed]

13. Tu, W.Y.; Simpson, J.E.; Highley, J.R.; Heath, P.R. Spinal muscular atrophy: Factors that modulate motor neurone vulnerability. Neurobiol. Dis. 2017, 102, 11-20. [CrossRef] [PubMed]

14. Rindt, H.; Feng, Z.; Mazzasette, C.; Glascock, J.J.; Valdivia, D.; Pyles, N.; Crawford, T.O.; Swoboda, K.J.; Patitucci, T.N.; Ebert, A.D.; et al. Astrocytes influence the severity of spinal muscular atrophy. Hum. Mol. Genet. 2015, 24, 4094-4102. [CrossRef] [PubMed]

15. Abati, E.; Citterio, G.; Bresolin, N.; Comi, G.P.; Corti, S. Glial cells involvement in spinal muscular atrophy: Could sma be a neuroinflammatory disease? Neurobiol. Dis. 2020, 140, 104870. [CrossRef] [PubMed]

16. Mercuri, E.; Bertini, E.; Iannaccone, S.T. Childhood spinal muscular atrophy: Controversies and challenges. Lancet Neurol. 2012, 11, 443-452. [CrossRef]

17. Nadeau, A.; D’Anjou, G.; Debray, G.; Robitaille, Y.; Simard, L.R.; Vanasse, M. A newborn with spinal muscular atrophy type 0 presenting with a clinicopathological picture suggestive of myotubular myopathy. J. Child. Neurol. 2007, 22, 1301-1304. [CrossRef]

18. Sansone, V.A.; Racca, F.; Ottonello, G.; Vianello, A.; Berardinelli, A.; Crescimanno, G.; Casiraghi, J.L.; Italian SMA Family Association. 1st Italian SMA Family Association Consensus Meeting: Management and recommendations for respiratory involvement in spinal muscular atrophy (SMA) types I-III, Rome, Italy, 30-31 January 2015. Neuromuscul. Disord. 2015, 25, 979-989. [CrossRef]

19. Wijngaarde, C.A.; Blank, A.C.; Stam, M.; Wadman, R.I.; van den Berg, L.H.; van der Pol, W.L. Cardiac pathology in spinal muscular atrophy: A systematic review. Orphanet J. Rare Dis. 2017, 12, 67. [CrossRef]

20. Kolb, S.J.; Coffey, C.S.; Yankey, J.W.; Krosschell, K.; Arnold, W.D.; Rutkove, S.B.; Swoboda, K.J.; Reyna, S.P.; Sakonju, A.; Darras, B.T.; et al. Natural history of infantile-onset spinal muscular atrophy. Ann. Neurol. 2017, 82, 883-891. [CrossRef]

21. Mercuri, E.; Finkel, R.S.; Muntoni, F.; Wirth, B.; Montes, J.; Main, M.; Mazzone, E.S.; Vitale, M.; Snyder, B.; Quijano-Roy, S.; et al. Diagnosis and management of spinal muscular atrophy: Part 1: Recommendations for diagnosis, rehabilitation, orthopedic and nutritional care. Neuromuscul. Disord. 2018, 28, 103-115. [CrossRef] 
22. Finkel, R.S.; Mercuri, E.; Meyer, O.H.; Simonds, A.K.; Schroth, M.K.; Graham, R.J.; Kirschner, J.; Iannaccone, S.T.; Crawford, T.O.; Woods, S.; et al. Diagnosis and management of spinal muscular atrophy: Part 2: Pulmonary and acute care; medications, supplements and immunizations; other organ systems; and ethics. Neuromuscul. Disord. 2018, 28, 197-207. [CrossRef] [PubMed]

23. Kaufmann, P.; McDermott, M.P.; Darras, B.T.; Finkel, R.; Kang, P.; Oskoui, M.; Constantinescu, A.; Sproule, D.M.; Foley, A.R.; Yang, M.; et al. Observational study of spinal muscular atrophy type 2 and 3: Functional outcomes over 1 year. Arch. Neurol. 2011, 68, 779-786. [CrossRef] [PubMed]

24. Piepers, S.; van den Berg, L.H.; Brugman, F.; Scheffer, H.; Ruiterkamp-Versteeg, M.; van Engelen, B.G.; Faber, C.G.; de Visser, M.; van der Pol, W.L.; Wokke, J.H. A natural history study of late onset spinal muscular atrophy types $3 \mathrm{~b}$ and 4. J. Neurol. 2008, 255, 1400-1404. [CrossRef] [PubMed]

25. Finkel, R.S.; McDermott, M.P.; Kaufmann, P.; Darras, B.T.; Chung, W.K.; Sproule, D.M.; Kang, P.B.; Foley, A.R.; Yang, M.L.; Martens, W.B.; et al. Observational study of spinal muscular atrophy type I and implications for clinical trials. Neurology 2014, 83, 810-817. [CrossRef] [PubMed]

26. Mercuri, E.; Lucibello, S.; Perulli, M.; Coratti, G.; de Sanctis, R.; Pera, M.C.; Pane, M.; Montes, J.; de Vivo, D.C.; Darras, B.T.; et al. Longitudinal natural history of type I spinal muscular atrophy: A critical review. Orphanet J. Rare Dis. 2020, 15, 84. [CrossRef]

27. Rudnik-Schoneborn, S.; Berg, C.; Zerres, K.; Betzler, C.; Grimm, T.; Eggermann, T.; Eggermann, K.; Wirth, R.; Wirth, B.; Heller, R. Genotype-phenotype studies in infantile spinal muscular atrophy (SMA) type I in Germany: Implications for clinical trials and genetic counselling. Clin. Genet. 2009, 76, 168-178. [CrossRef]

28. Tizzano, E.F.; Finkel, R.S. Spinal muscular atrophy: A changing phenotype beyond the clinical trials. Neuromuscul. Disord. 2017, 27, 883-889. [CrossRef]

29. Sansone, V.A.; Pirola, A.; Albamonte, E.; Pane, M.; Lizio, A.; D’Amico, A.; Catteruccia, M.; Cutrera, R.; Bruno, C.; Pedemonte, M.; et al. Respiratory Needs in Patients with Type 1 Spinal Muscular Atrophy Treated with Nusinersen. J. Pediatr. 2020, 219, 223-228.e4. [CrossRef]

30. Farrar, M.A.; Park, S.B.; Vucic, S.; Carey, K.A.; Turner, B.J.; Gillingwater, T.H.; Swoboda, K.J.; Kiernan, M.C. Emerging therapies and challenges in spinal muscular atrophy. Ann. Neurol. 2017, 81, 355-368. [CrossRef]

31. Wang, C.H.; Finkel, R.S.; Bertini, E.S.; Schroth, M.; Simonds, A.; Wong, B.; Aloysius, A.; Morrison, L.; Main, M.; Crawford, T.O.; et al. Consensus statement for standard of care in spinal muscular atrophy. J. Child. Neurol. 2007, 22, 1027-1049. [CrossRef]

32. Feldkotter, M.; Schwarzer, V.; Wirth, R.; Wienker, T.F.; Wirth, B. Quantitative analyses of SMN1 and SMN2 based on real-time lightCycler PCR: Fast and highly reliable carrier testing and prediction of severity of spinal muscular atrophy. Am. J. Hum. Genet. 2002, 70, 358-368. [CrossRef] [PubMed]

33. Burnett, B.G.; Crawford, T.O.; Sumner, C.J. Emerging treatment options for spinal muscular atrophy. Curr. Treat. Options Neurol. 2009, 11, 90-101. [CrossRef] [PubMed]

34. Chang, J.G.; Hsieh-Li, H.M.; Jong, Y.J.; Wang, N.M.; Tsai, C.H.; Li, H. Treatment of spinal muscular atrophy by sodium butyrate. Proc. Natl. Acad. Sci. USA 2001, 98, 9808-9813. [CrossRef] [PubMed]

35. Schreml, J.; Riessland, M.; Paterno, M.; Garbes, L.; Rossbach, K.; Ackermann, B.; Kramer, J.; Somers, E.; Parson, S.H.; Heller, R.; et al. Severe sma mice show organ impairment that cannot be rescued by therapy with the HDACi JNJ-26481585. Eur. J. Hum. Genet. 2013, 21, 643-652. [CrossRef]

36. Somers, E.; Lees, R.D.; Hoban, K.; Sleigh, J.N.; Zhou, H.; Muntoni, F.; Talbot, K.; Gillingwater, T.H.; Parson, S.H. Vascular defects and spinal cord hypoxia in spinal muscular atrophy. Ann. Neurol. 2016, 79, $217-230$. [CrossRef]

37. Deguise, M.O.; De Repentigny, Y.; McFall, E.; Auclair, N.; Sad, S.; Kothary, R. Immune dysregulation may contribute to disease pathogenesis in spinal muscular atrophy mice. Hum. Mol. Genet. 2017, 26, 801-819. [CrossRef]

38. Nery, F.C.; Siranosian, J.J.; Rosales, I.; Deguise, M.O.; Sharma, A.; Muhtaseb, A.W.; Nwe, P.; Johnstone, A.J.; Zhang, R.; Fatouraei, M.; et al. Impaired kidney structure and function in spinal muscular atrophy. Neurol. Genet. 2019, 5, e353. [CrossRef]

39. Mendell, J.R.; Al-Zaidy, S.; Shell, R.; Arnold, W.D.; Rodino-Klapac, L.R.; Prior, T.W.; Lowes, L.; Alfano, L.; Berry, K.; Church, K.; et al. Single-Dose Gene-Replacement Therapy for Spinal Muscular Atrophy. N. Engl. J. Med. 2017, 377, 1713-1722. [CrossRef] 
40. Finkel, R.S.; Mercuri, E.; Darras, B.T.; Connolly, A.M.; Kuntz, N.L.; Kirschner, J.; Chiriboga, C.A.; Saito, K.; Servais, L.; Tizzano, E.; et al. Nusinersen versus Sham Control in Infantile-Onset Spinal Muscular Atrophy. N. Engl. J. Med. 2017, 377, 1723-1732. [CrossRef]

41. Wadman, R.I.; van der Pol, W.L.; Bosboom, W.M.; Asselman, F.L.; van den Berg, L.H.; Iannaccone, S.T.; Vrancken, A.F. Drug treatment for spinal muscular atrophy types II and III. Cochrane Database Syst. Rev. 2020, 1, CD006282. [CrossRef]

42. Perego, M.G.L.; Galli, N.; Nizzardo, M.; Govoni, A.; Taiana, M.; Bresolin, N.; Comi, G.P.; Corti, S. Current understanding of and emerging treatment options for spinal muscular atrophy with respiratory distress type 1 (SMARD1). Cell. Mol. Life Sci. 2020, in press. [CrossRef] [PubMed]

43. Lunke, S.; El-Osta, A. Applicability of histone deacetylase inhibition for the treatment of spinal muscular atrophy. Neurotherapeutics 2013, 10, 677-687. [CrossRef] [PubMed]

44. Wadman, R.I.; van der Pol, W.L.; Bosboom, W.M.; Asselman, F.L.; van den Berg, L.H.; Iannaccone, S.T.; Vrancken, A.F. Drug treatment for spinal muscular atrophy type I. Cochrane Database Syst. Rev. 2019, 12, CD006281. [CrossRef] [PubMed]

45. Mohseni, J.; Zabidi-Hussin, Z.A.; Sasongko, T.H. Histone deacetylase inhibitors as potential treatment for spinal muscular atrophy. Genet. Mol. Biol. 2013, 36, 299-307. [CrossRef]

46. Calder, A.N.; Androphy, E.J.; Hodgetts, K.J. Small Molecules in Development for the Treatment of Spinal Muscular Atrophy. J. Med. Chem. 2016, 59, 10067-10083. [CrossRef] [PubMed]

47. Strahl, B.D.; Allis, C.D. The language of covalent histone modifications. Nature 2000, 403, 41-45. [CrossRef]

48. Grzeschik, S.M.; Ganta, M.; Prior, T.W.; Heavlin, W.D.; Wang, C.H. Hydroxyurea enhances SMN2 gene expression in spinal muscular atrophy cells. Ann. Neurol. 2005, 58, 194-202. [CrossRef]

49. Liang, W.C.; Yuo, C.Y.; Chang, J.G.; Chen, Y.C.; Chang, Y.F.; Wang, H.Y.; Ju, Y.H.; Chiou, S.S.; Jong, Y.J. The effect of hydroxyurea in spinal muscular atrophy cells and patients. J. Neurol. Sci. 2008, 268, 87-94. [CrossRef]

50. Chen, T.H.; Chang, J.G.; Yang, Y.H.; Mai, H.H.; Liang, W.C.; Wu, Y.C.; Wang, H.Y.; Huang, Y.B.; Wu, S.M.; Chen, Y.C.; et al. Randomized, double-blind, placebo-controlled trial of hydroxyurea in spinal muscular atrophy. Neurology 2010, 75, 2190-2197. [CrossRef]

51. Angelozzi, C.; Borgo, F.; Tiziano, F.D.; Martella, A.; Neri, G.; Brahe, C. Salbutamol increases SMN mRNA and protein levels in spinal muscular atrophy cells. J. Med. Genet. 2008, 45, 29-31. [CrossRef]

52. Kinali, M.; Mercuri, E.; Main, M.; De Biasia, F.; Karatza, A.; Higgins, R.; Banks, L.M.; Manzur, A.Y.; Muntoni, F. Pilot trial of albuterol in spinal muscular atrophy. Neurology 2002, 59, 609-610. [CrossRef] [PubMed]

53. Pane, M.; Staccioli, S.; Messina, S.; D'Amico, A.; Pelliccioni, M.; Mazzone, E.S.; Cuttini, M.; Alfieri, P.; Battini, R.; Main, M.; et al. Daily salbutamol in young patients with SMA type II. Neuromuscul. Disord. 2008, 18, 536-540. [CrossRef] [PubMed]

54. Chen, T.H.; Yang, Y.H.; Mai, H.H.; Liang, W.C.; Wu, Y.C.; Wang, H.Y.; Jong, Y.J. Reliability and validity of outcome measures of in-hospital and at-home visits in a randomized, double-blind, placebo-controlled trial for spinal muscular atrophy. J. Child. Neurol. 2014, 29, 1680-1684. [CrossRef] [PubMed]

55. Singh, N.N.; Shishimorova, M.; Cao, L.C.; Gangwani, L.; Singh, R.N. A short antisense oligonucleotide masking a unique intronic motif prevents skipping of a critical exon in spinal muscular atrophy. RNA Biol. 2009, 6, 341-350. [CrossRef]

56. Hua, Y.; Vickers, T.A.; Okunola, H.L.; Bennett, C.F.; Krainer, A.R. Antisense masking of an hnRNP A1/A2 intronic splicing silencer corrects SMN2 splicing in transgenic mice. Am. J. Hum. Genet. 2008, 82, 834-848. [CrossRef]

57. Porensky, P.N.; Mitrpant, C.; McGovern, V.L.; Bevan, A.K.; Foust, K.D.; Kaspar, B.K.; Wilton, S.D.; Burghes, A.H. A single administration of morpholino antisense oligomer rescues spinal muscular atrophy in mouse. Hum. Mol. Genet. 2012, 21, 1625-1638. [CrossRef]

58. Chiriboga, C.A.; Swoboda, K.J.; Darras, B.T.; Iannaccone, S.T.; Montes, J.; De Vivo, D.C.; Norris, D.A.; Bennett, C.F.; Bishop, K.M. Results from a phase 1 study of nusinersen (ISIS-SMNRx) in children with spinal muscular atrophy. Neurology 2016, 86, 890-897. [CrossRef]

59. Kariya, S.; Obis, T.; Garone, C.; Akay, T.; Sera, F.; Iwata, S.; Homma, S.; Monani, U.R. Requirement of enhanced survival motoneuron protein imposed during neuromuscular junction maturation. J. Clin. Invest. 2014, 124, 785-800. [CrossRef] 
60. De Vivo, D.C.; Bertini, E.; Swoboda, K.J.; Hwu, W.L.; Crawford, T.O.; Finkel, R.S.; Kirschner, J.; Kuntz, N.L.; Parsons, J.A.; Ryan, M.M.; et al. Nusinersen initiated in infants during the presymptomatic stage of spinal muscular atrophy: Interim efficacy and safety results from the Phase 2 NURTURE study. Neuromuscul. Disord. 2019, 29, 842-856. [CrossRef]

61. Dangouloff, T.; Burghes, A.; Tizzano, E.F.; Servais, L.; NBS SMA Study Group. 244th ENMC international workshop: Newborn screening in spinal muscular atrophy May 10-12, 2019, Hoofdorp, The Netherlands. Neuromuscul. Disord. 2020, 30, 93-103. [CrossRef]

62. Kariyawasam, D.S.T.; Russell, J.S.; Wiley, V.; Alexander, I.E.; Farrar, M.A. The implementation of newborn screening for spinal muscular atrophy: The Australian experience. Genet. Med. 2020, 22, 557-565. [CrossRef]

63. Mercuri, E.; Darras, B.T.; Chiriboga, C.A.; Day, J.W.; Campbell, C.; Connolly, A.M.; Iannaccone, S.T.; Kirschner, J.; Kuntz, N.L.; Saito, K.; et al. Nusinersen versus Sham Control in Later-Onset Spinal Muscular Atrophy. N. Engl. J. Med. 2018, 378, 625-635. [CrossRef]

64. Gidaro, T.; Servais, L. Nusinersen treatment of spinal muscular atrophy: Current knowledge and existing gaps. Dev. Med. Child. Neurol. 2019, 61, 19-24. [CrossRef]

65. Talbot, K.; Tizzano, E.F. The clinical landscape for SMA in a new therapeutic era. Gene. Ther. 2017, 24, 529-533. [CrossRef]

66. Nash, L.A.; Burns, J.K.; Chardon, J.W.; Kothary, R.; Parks, R.J. Spinal Muscular Atrophy: More than a Disease of Motor Neurons? Curr. Mol. Med. 2016, 16, 779-792. [CrossRef]

67. Kim, J.K.; Jha, N.N.; Feng, Z.; Faleiro, M.R.; Chiriboga, C.A.; Wei-Lapierre, L.; Dirksen, R.T.; Ko, C.P.; Monani, U.R. Muscle-specific smn reduction reveals motor neuron-independent disease in spinal muscular atrophy models. J. Clin. Investig. 2020, 130, 1271-1287. [CrossRef]

68. Hua, Y.; Sahashi, K.; Rigo, F.; Hung, G.; Horev, G.; Bennett, C.F.; Krainer, A.R. Peripheral SMN restoration is essential for long-term rescue of a severe spinal muscular atrophy mouse model. Nature 2011, 478, 123-126. [CrossRef]

69. Hua, Y.; Liu, Y.H.; Sahashi, K.; Rigo, F.; Bennett, C.F.; Krainer, A.R. Motor neuron cell-nonautonomous rescue of spinal muscular atrophy phenotypes in mild and severe transgenic mouse models. Genes Dev. 2015, 29, 288-297. [CrossRef]

70. Al-Zaidy, S.A.; Mendell, J.R. From Clinical Trials to Clinical Practice: Practical Considerations for Gene Replacement Therapy in SMA Type 1. Pediatr. Neurol. 2019, 100, 3-11. [CrossRef]

71. McCarty, D.M.; Monahan, P.E.; Samulski, R.J. Self-complementary recombinant adeno-associated virus (scAAV) vectors promote efficient transduction independently of DNA synthesis. Gene Ther. 2001, 8, 1248-1254. [CrossRef]

72. Foust, K.D.; Wang, X.; McGovern, V.L.; Braun, L.; Bevan, A.K.; Haidet, A.M.; Le, T.T.; Morales, P.R.; Rich, M.M.; Burghes, A.H.; et al. Rescue of the spinal muscular atrophy phenotype in a mouse model by early postnatal delivery of SMN. Nat. Biotechnol. 2010, 28, 271-274. [CrossRef]

73. Lowes, L.P.; Alfano, L.N.; Arnold, W.D.; Shell, R.; Prior, T.W.; McColly, M.; Lehman, K.J.; Church, K.; Sproule, D.M.; Nagendran, S.; et al. Impact of Age and Motor Function in a Phase 1/2A Study of Infants With SMA Type 1 Receiving Single-Dose Gene Replacement Therapy. Pediatr. Neurol. 2019, 98, 39-45. [CrossRef]

74. Shell, R.; Day, J.W.; Chiriboga, C.A.; Crawford, T.O.; Darras, B.T.; Finkel, R.S.; Connolly, A.M.; Lannaccone, S.T.; Kuntz, N.L.; Peña, L.D.M.; et al. Onasemnogene Abeparvovec Gene-Replacement Therapy for Spinal Muscular Atrophy Type 1: Pivotal Phase 3 Study (STR1VE) Update. In Proceedings of the CureSMA 23rd Annual SMA Researcher Meeting, Anaheim, CA, USA, 28-30 June 2019.

75. Novartis. Novartis Announces AVXS-101 Intrathecal Study Update. Available online: https://www. novartis.com/news/media-releases/novartis-announces-avxs-101-intrathecal-study-update (accessed on 30 March 2020).

76. van der Ploeg, A.T. The Dilemma of Two Innovative Therapies for Spinal Muscular Atrophy. N. Engl. J. Med. 2017, 377, 1786-1787. [CrossRef] [PubMed]

77. Pan, X.; Yue, Y.; Zhang, K.; Hakim, C.H.; Kodippili, K.; McDonald, T.; Duan, D. AAV-8 is more efficient than AAV-9 in transducing neonatal dog heart. Hum. Gene Ther. Methods 2015, 26, 54-61. [CrossRef]

78. Hinderer, C.; Katz, N.; Buza, E.L.; Dyer, C.; Goode, T.; Bell, P.; Richman, L.K.; Wilson, J.M. Severe Toxicity in Nonhuman Primates and Piglets Following High-Dose Intravenous Administration of an Adeno-Associated Virus Vector Expressing Human SMN. Hum. Gene Ther. 2018, 29, 285-298. [CrossRef] 
79. Colella, P.; Ronzitti, G.; Mingozzi, F. Emerging Issues in AAV-Mediated In Vivo Gene Therapy. Molecul. Ther. Mol. Ther. Methods Clin. Dev. 2018, 8, 87-104. [CrossRef]

80. Palacino, J.; Swalley, S.E.; Song, C.; Cheung, A.K.; Shu, L.; Zhang, X.; Van Hoosear, M.; Shin, Y.; Chin, D.N.; Keller, C.G.; et al. SMN2 splice modulators enhance U1-pre-mRNA association and rescue SMA mice. Nat. Chem. Biol. 2015, 11, 511-517. [CrossRef]

81. Kletzl, H.; Marquet, A.; Gunther, A.; Tang, W.; Heuberger, J.; Groeneveld, G.J.; Birkhoff, W.; Mercuri, E.; Lochmuller, H.; Wood, C.; et al. The oral splicing modifier RG7800 increases full length survival of motor neuron 2 mRNA and survival of motor neuron protein: Results from trials in healthy adults and patients with spinal muscular atrophy. Neuromuscul. Disord. 2019, 29, 21-29. [CrossRef]

82. Ratni, H.; Ebeling, M.; Baird, J.; Bendels, S.; Bylund, J.; Chen, K.S.; Denk, N.; Feng, Z.; Green, L.; Guerard, M.; et al. Discovery of Risdiplam, a Selective Survival of Motor Neuron-2 ( SMN2) Gene Splicing Modifier for the Treatment of Spinal Muscular Atrophy (SMA). J. Med. Chem. 2018, 61, 6501-6517. [CrossRef]

83. Sturm, S.; Gunther, A.; Jaber, B.; Jordan, P.; Al Kotbi, N.; Parkar, N.; Cleary, Y.; Frances, N.; Bergauer, T.; Heinig, K.; et al. A phase 1 healthy male volunteer single escalating dose study of the pharmacokinetics and pharmacodynamics of risdiplam (RG7916, RO7034067), a SMN2 splicing modifier. Br. J. Clin. Pharmacol. 2019, 85, 181-193. [CrossRef]

84. Seabrook, T.; Baranello, G.; Servais, L.; Day, J.W.; Deconinck, N.; Mercuri, E.; Klein, A.; Darras, B.; Masson1, R.; Kletzl11, H.; et al. FIREFISH part 1: Early clinical results following an increase of SMN protein in infants with type 1 spinal muscular atrophy (SMA) treated with Risdiplam (RG7916). In Proceedings of the Communication Presented at MDA Clinical \& Scientific Conference, Orlando, FL, USA, 13-17 April 2019.

85. Roche. Roche's Risdiplam Meets Primary Endpoint in Pivotal SUNFISH Trial in People with Type 2 or 3 Spinal Muscular Atrophy. Available online: https://www.roche.com/media/releases/med-cor-2019-11-11.htm (accessed on 16 March 2019).

86. Cheung, A.K.; Hurley, B.; Kerrigan, R.; Shu, L.; Chin, D.N.; Shen, Y.; O’Brien, G.; Sung, M.J.; Hou, Y.; Axford, J.; et al. Discovery of Small Molecule Splicing Modulators of Survival Motor Neuron-2 (SMN2) for the Treatment of Spinal Muscular Atrophy (SMA). J. Med. Chem. 2018, 61, 11021-11036. [CrossRef] [PubMed]

87. Jevtic, S.; Carr, D.; Dobrzycka-Ambrozevicz, A. Branaplam in Type 1 spinal muscular atrophy: Second part of a phase I/II Study. In Proceedings of the CureSMA 23rd Annual SMA Researcher Meeting, Anaheim, CA, USA, 28-30 June 2019.

88. Farooq, F.; Abadia-Molina, F.; MacKenzie, D.; Hadwen, J.; Shamim, F.; O’Reilly, S.; Holcik, M.; MacKenzie, A. Celecoxib increases SMN and survival in a severe spinal muscular atrophy mouse model via p38 pathway activation. Hum. Mol. Genet. 2013, 22, 3415-3424. [CrossRef] [PubMed]

89. Jarecki, J.; Chen, X.; Bernardino, A.; Coovert, D.D.; Whitney, M.; Burghes, A.; Stack, J.; Pollok, B.A. Diverse small-molecule modulators of SMN expression found by high-throughput compound screening: Early leads towards a therapeutic for spinal muscular atrophy. Hum. Mol. Genet. 2005, 14, 2003-2018. [CrossRef] [PubMed]

90. Gogliotti, R.G.; Cardona, H.; Singh, J.; Bail, S.; Emery, C.; Kuntz, N.; Jorgensen, M.; Durens, M.; Xia, B.; Barlow, C.; et al. The DcpS inhibitor RG3039 improves survival, function and motor unit pathologies in two SMA mouse models. Hum. Mol. Genet. 2013, 22, 4084-4101. [CrossRef]

91. Jedrzejowska, M.; Kostera-Pruszczyk, A. Spinal muscular atrophy - new therapies, new challenges. Neurol. Neurochir. Polska 2020, 54, 8-13. [CrossRef]

92. Van Meerbeke, J.; Gibbs, R.; Plasterer, H.; Feng, Z.; Lin, M.-Y.; Wee, C.; Xia, B.; Jacques, V.; Rusche, J.; Ko, C.-P.; et al. The Therapeutic Effects of RG3039 in Severe Spinal Muscular Atrophy Mice and Normal Human Volunteers (S25.003). Neurology 2012, 78, S25. [CrossRef]

93. Heier, C.R.; DiDonato, C.J. Translational readthrough by the aminoglycoside geneticin (G418) modulates SMN stability in vitro and improves motor function in SMA mice in vivo. Hum. Mol. Genet. 2009, 18, 1310-1322. [CrossRef]

94. Cobb, M.S.; Rose, F.F.; Rindt, H.; Glascock, J.J.; Shababi, M.; Miller, M.R.; Osman, E.Y.; Yen, P.F.; Garcia, M.L.; Martin, B.R.; et al. Development and characterization of an SMN2-based intermediate mouse model of Spinal Muscular Atrophy. Hum. Mol. Genet. 2013, 22, 1843-1855. [CrossRef] 
95. Greif, H.; Rosin-Arbesfeld, R.; Megiddo, D. BBrm2, A Read-through Repurposed Drug, Shows Proof of Efficacy in SMA Treatment. In Proceedings of the Cure SMA 19th Annual SMA Researcher Meeting, Kansas City, MO, USA, 18-20 June 2015.

96. Kwon, D.Y.; Motley, W.W.; Fischbeck, K.H.; Burnett, B.G. Increasing expression and decreasing degradation of SMN ameliorate the spinal muscular atrophy phenotype in mice. Hum. Mol. Genet. 2011, 20, 3667-3677. [CrossRef]

97. Kaifer, K.A.; Villalon, E.; Osman, E.Y.; Glascock, J.J.; Arnold, L.L.; Cornelison, D.D.W.; Lorson, C.L. Plastin-3 extends survival and reduces severity in mouse models of spinal muscular atrophy. JCI Insight 2017, 2, e89970. [CrossRef]

98. Sumner, C.J.; Crawford, T.O. Two breakthrough gene-targeted treatments for spinal muscular atrophy: Challenges remain. J. Clin. Investig. 2018, 128, 3219-3227. [CrossRef] [PubMed]

99. Bordet, T.; Buisson, B.; Michaud, M.; Drouot, C.; Galea, P.; Delaage, P.; Akentieva, N.P.; Evers, A.S.; Covey, D.F.; Ostuni, M.A.; et al. Identification and characterization of cholest-4-en-3-one, oxime (TRO19622), a novel drug candidate for amyotrophic lateral sclerosis. J. Pharmacol. Exp. Ther. 2007, 322, 709-720. [CrossRef] [PubMed]

100. Bertini, E.; Dessaud, E.; Mercuri, E.; Muntoni, F.; Kirschner, J.; Reid, C.; Lusakowska, A.; Comi, G.P.; Cuisset, J.M.; Abitbol, J.L.; et al. Safety and efficacy of olesoxime in patients with type 2 or non-ambulatory type 3 spinal muscular atrophy: A randomised, double-blind, placebo-controlled phase 2 trial. Lancet Neurol. 2017, 16, 513-522. [CrossRef]

101. Haddad, H.; Cifuentes-Diaz, C.; Miroglio, A.; Roblot, N.; Joshi, V.; Melki, J. Riluzole attenuates spinal muscular atrophy disease progression in a mouse model. Muscle Nerve 2003, 28, 432-437. [CrossRef]

102. Merlini, L.; Solari, A.; Vita, G.; Bertini, E.; Minetti, C.; Mongini, T.; Mazzoni, E.; Angelini, C.; Morandi, L. Role of gabapentin in spinal muscular atrophy: Results of a multicenter, randomized Italian study. J. Child. Neurol. 2003, 18, 537-541. [CrossRef]

103. Pirruccello-Straub, M.; Jackson, J.; Wawersik, S.; Webster, M.T.; Salta, L.; Long, K.; McConaughy, W.; Capili, A.; Boston, C.; Carven, G.J.; et al. Blocking extracellular activation of myostatin as a strategy for treating muscle wasting. Sci. Rep. 2018, 8, 2292. [CrossRef]

104. Feng, Z.; Ling, K.K.; Zhao, X.; Zhou, C.; Karp, G.; Welch, E.M.; Naryshkin, N.; Ratni, H.; Chen, K.S.; Metzger, F.; et al. Pharmacologically induced mouse model of adult spinal muscular atrophy to evaluate effectiveness of therapeutics after disease onset. Hum. Mol. Genet. 2016, 25, 964-975. [CrossRef]

105. Liu, M.; Hammers, D.W.; Barton, E.R.; Sweeney, H.L. Activin Receptor Type IIB Inhibition Improves Muscle Phenotype and Function in a Mouse Model of Spinal Muscular Atrophy. PLoS ONE 2016, 11, e0166803. [CrossRef]

106. AliveGen. R\&D Pipeline: ALG-801. Available online: http://www.alivegen.com/r-d-pipeline (accessed on 22 April 2020).

107. Long, K.K.; O’Shea, K.M.; Khairallah, R.J.; Howell, K.; Paushkin, S.; Chen, K.S.; Cote, S.M.; Webster, M.T.; Stains, J.P.; Treece, E.; et al. Specific inhibition of myostatin activation is beneficial in mouse models of SMA therapy. Hum. Mol. Genet. 2019, 28, 1076-1089. [CrossRef]

108. Chyung, Y. Interim Results from a Phase 1 Study of SRK-015, a Fully Human Monoclonal Antibody that Inhibits Myostatin Activation. In Proceedings of the CureSMA 23rd Annual SMA Researcher Meeting, Anaheim, CA, USA, 28-30 June 2019.

109. Hwee, D.T.; Kennedy, A.R.; Hartman, J.J.; Ryans, J.; Durham, N.; Malik, F.I.; Jasper, J.R. The small-molecule fast skeletal troponin activator, CK-2127107, improves exercise tolerance in a rat model of heart failure. J. Pharmacol. Exp. Ther. 2015, 353, 159-168. [CrossRef]

110. Andrews, J.A.; Miller, T.M.; Vijayakumar, V.; Stoltz, R.; James, J.K.; Meng, L.; Wolff, A.A.; Malik, F.I. CK-2127107 amplifies skeletal muscle response to nerve activation in humans. Muscle Nerve 2018, 57, 729-734. [CrossRef] [PubMed]

111. Day, J.W. Update of CY 5021: A Phase 2 Clinical Trial of Reldesemtiv, a Fast Skeletal Muscle Troponin Activator (FSTA), for the Potential Treatment of Spinal Muscular Atrophy. In Proceedings of the CureSMA 22nd Annual SMA Researcher Meeting, Dallas, TX, USA, 14-16 June 2018.

112. Wadman, R.I.; Vrancken, A.F.; van den Berg, L.H.; van der Pol, W.L. Dysfunction of the neuromuscular junction in spinal muscular atrophy types 2 and 3. Neurology 2012, 79, 2050-2055. [CrossRef] [PubMed] 
113. Stam, M.; Wadman, R.I.; Wijngaarde, C.A.; Bartels, B.; Asselman, F.L.; Otto, L.A.M.; Goedee, H.S.; Habets, L.E.; de Groot, J.F.; Schoenmakers, M.; et al. Protocol for a phase II, monocentre, double-blind, placebo-controlled, cross-over trial to assess efficacy of pyridostigmine in patients with spinal muscular atrophy types 2-4 (SPACE trial). BMJ Open 2018, 8, e019932. [CrossRef] [PubMed]

114. Imlach, W.L.; Beck, E.S.; Choi, B.J.; Lotti, F.; Pellizzoni, L.; McCabe, B.D. SMN is required for sensory-motor circuit function in Drosophila. Cell 2012, 151, 427-439. [CrossRef]

115. Pandolfi, F.; De Vita, D.; Bortolami, M.; Coluccia, A.; Di Santo, R.; Costi, R.; Andrisano, V.; Alabiso, F.; Bergamini, C.; Fato, R.; et al. New pyridine derivatives as inhibitors of acetylcholinesterase and amyloid aggregation. Eur. J. Med. Chem. 2017, 141, 197-210. [CrossRef]

116. Ebert, A.D.; Yu, J.; Rose, F.F., Jr.; Mattis, V.B.; Lorson, C.L.; Thomson, J.A.; Svendsen, C.N. Induced pluripotent stem cells from a spinal muscular atrophy patient. Nature 2009, 457, 277-280. [CrossRef]

117. Corti, S.; Nizzardo, M.; Nardini, M.; Donadoni, C.; Salani, S.; Ronchi, D.; Saladino, F.; Bordoni, A.; Fortunato, F.; Del Bo, R.; et al. Neural stem cell transplantation can ameliorate the phenotype of a mouse model of spinal muscular atrophy. J. Clin. Investig. 2008, 118, 3316-3330. [CrossRef]

118. Corti, S.; Nizzardo, M.; Nardini, M.; Donadoni, C.; Salani, S.; Ronchi, D.; Simone, C.; Falcone, M.; Papadimitriou, D.; Locatelli, F.; et al. Embryonic stem cell-derived neural stem cells improve spinal muscular atrophy phenotype in mice. Brain 2010, 133, 465-481. [CrossRef]

119. Poletti, A.; Fischbeck, K.H. Combinatorial treatment for spinal muscular atrophy: An Editorial for 'Combined treatment with the histone deacetylase inhibitor LBH589 and a splice-switch antisense oligonucleotide enhances SMN2 splicing and SMN expression in Spinal Muscular Atrophy cells' on page 264. J. Neurochem. 2020, 153, 146-149.

120. Zhou, H.; Meng, J.; Malerba, A.; Catapano, F.; Sintusek, P.; Jarmin, S.; Feng, L.; Lu-Nguyen, N.; Sun, L.; Mariot, V.; et al. Myostatin inhibition in combination with antisense oligonucleotide therapy improves outcomes in spinal muscular atrophy. J. Cachexia Sarcopenia Muscle 2020, in press. [CrossRef]

121. Lee, B.H.; Collins, E.; Lewis, L.; Guntrum, D.; Eichinger, K.; Voter, K.; Abdel-Hamid, H.Z.; Ciafaloni, E. Combination therapy with nusinersen and AVXS-101 in SMA type 1. Neurology 2019, 93, 640-641. [CrossRef] [PubMed]

(C) 2020 by the author. Licensee MDPI, Basel, Switzerland. This article is an open access article distributed under the terms and conditions of the Creative Commons Attribution (CC BY) license (http://creativecommons.org/licenses/by/4.0/). 